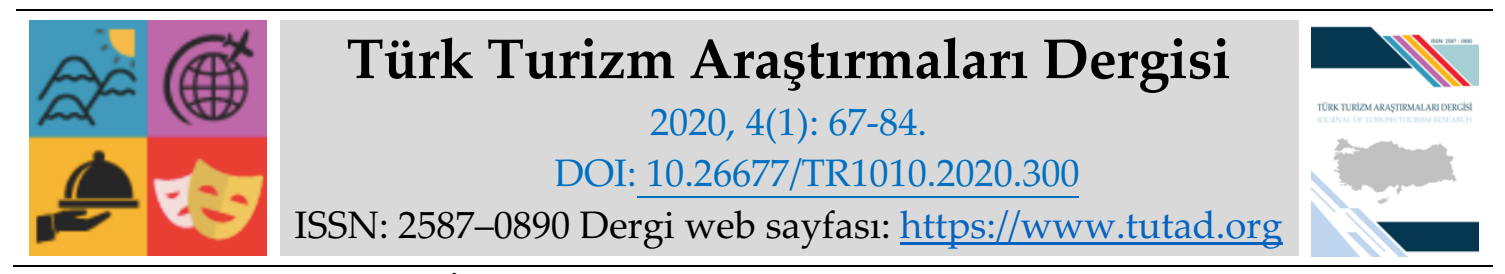

ARASTTIRMA MAKALESI

\title{
Üniversite Öğrencilerinin Sürdürülebilir Turizme Yönelik Tutumları: Mehmet Akif Ersoy Üniversitesi Örneği
}

Dr. Öğr. Üyesi, Olcay KİİNÇ, Burdur Mehmet Akif Ersoy Üniversitesi Turizm İşletmeciliği ve Otelcilik Yüksekokulu, Burdur, e-posta: olcaykilinc@mehmetakif.edu.tr

ORCID: https://orcid.org/0000-0002-1369-3139

Dr. Öğr. Üyesi, Uğur KİLiNÇ, Burdur Mehmet Akif Ersoy Üniversitesi Turizm İşletmeciliği ve Otelcilik Yüksekokulu, Burdur, e-posta: ugurkilinc@mehmetakif.edu.tr

ORCID: https://orcid.org/0000-0001-6412-2689

Dr. Öğr. Üyesi, Utku ONGUN, Burdur Mehmet Akif Ersoy Üniversitesi Turizm İşletmeciliği ve Otelcilik Yüksekokulu, Burdur, e-posta: utkuongun@mehmetakif.edu.tr

ORCID: https://orcid.org/0000-0002-0722-6382

\section{Öz}

Turizm genel olarak gerçekleştirildiği çevredeki doğal, tarihi ve diğer çekiciliklerin alt ve üst yapı olanakları ile birlikte desteklenerek tüketicilere sunulması ile ortaya çıkan bir olgudur. Bu nedenle çekim yerlerinin turistik ürünlerini sunmaya devam edebilmesi ve turizm potansiyellerini arttırabilmesi her şeyden önce turizmin sürdürülebilirliğine bağlıdır. Bir bölgede turizmin sürdürülebilir olması paydaşların sürdürülebilirlik tutumlarına yüksek oranda bağlıdır. Üniversite öğrencileri bir yandan seyahat etme ve turizme katılma düzeylerinin yüksekliği ile turist olarak, diğer yandan turizm eğitimi alan öğrenciler başta olmak üzere aldıkları eğitim ve gelecekte ulaşacakları sosyal statü nedeni ile turizm geleceğini şekillendirme potansiyelleri ile önemli paydaşlar olarak görülmelidir. Araştırmada üniversite öğrencilerinin turizm sürdürülebilirliği üzerine tutumları ölçülmesi amaçlanmıştır. Bu amaç doğrultusunda araştırma, nicel araştırmalar içerisinde yer alan betimleyici yani durum saptayıcı bir araştırma olarak planlanmıştır. Araştırmada, Suk ve arkadaşları (2005) tarafından geliştirilen 38 ifadeden oluşan 7 boyutlu yerel halkın sürdürülebilir turizm tutumlarını ölçmek için kullandıkları ölçüm aracından yararlanılmıştır. Araştırmada birincil veri kaynakları kullanılmıştır. Araştırma verilerinin toplanmasında katılımcıların turizm sürdürülebilirliği üzerine tutumlarını ölçmeye yönelik olarak bir soru formu düzenlenmiş ve soru formları yüz yüze görüşme tekniği ile cevaplandırılarak araştırma verileri elde edilmiştir. Araştırma alternatif turizm türleri açısından birçok çeşitliliğe sahip Burdur ilinde eğitim gören Mehmet Akif Ersoy Üniversitesi öğrencileri ile gerçekleştirilmiştir. Araştırmada öğrencilerin eğitim gördükleri bölüm, tatil deneyimlerinin olup olmaması, yılda geçirilen ortalama tatil süresi, tatilde konaklanan işletme türü, aylık ortalama harcama miktarı, Burdur'da yaşam süreleri ve cinsiyet ile açklayıcı faktör analizi sonucunda ortaya çıkan turizm sürdürülebilirliği tutumlarının yedi alt boyutu arasındaki ilişki incelenmiştir. Araştırmada hipotez, korelasyon ve kümeleme testleri kullanılmıştır. Araştırma sonucunda üniversite öğrencilerinin eğitim gördükleri bölüm, tatil deneyimde konaklanan işletme türü, konaklama süresi ve cinsiyet değişkenleri ile turizm sürdürülebilirliği tutumları arasında ilişki olduğu görülmüştür.

Anahtar Kelimeler: Turizm, Sürdürülebilirlik, Üniversite Öğrencileri.

Makale Gönderme Tarihi: 08.10.2019

Makale Kabul Tarihi: 15.01 .2020

Önerilen Atıf:

Kilinç, O., Kilinç, U. ve Ongun, U. (2020). Üniversite Öğrencilerinin Sürdürülebilir Turizme Yönelik Tutumları: Mehmet Akif Ersoy Üniversitesi Örneği, Türk Turizm Araştırmaları Dergisi, 4(1): 67-84.

(c) 2020 Türk Turizm Araştırmaları Dergisi. 


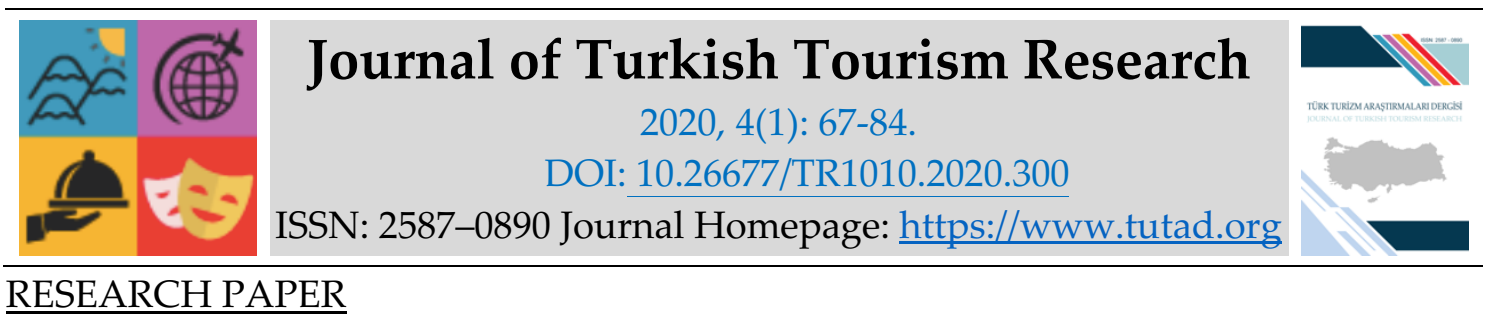

\title{
University Students' Attitudes towards Sustainable Tourism: The Case of Mehmet Akif Ersoy University
}

Assistant Prof. Dr. Olcay KİLİNÇ, Burdur Mehmet Akif Ersoy University, School of Tourism and Hotel Management, Burdur, e-mail: olcaykilinc@mehmetakif.edu.tr ORCID: https://orcid.org/0000-0002-1369-3139

Assistant Prof. Dr. Uğur KILİNÇ, Burdur Mehmet Akif Ersoy University, School of Tourism and Hotel Management, Burdur, e-mail: ugurkilinc@mehmetakif.edu.tr ORCID: https://orcid.org/0000-0001-6412-2689

Assistant Prof. Dr. Utku ONGUN, Burdur Mehmet Akif Ersoy University, School of Tourism and Hotel Management, Burdur, e-mail: utkuongun@mehmetakif.edu.tr

ORCID: https://orcid.org/0000-0002-0722-6382

\begin{abstract}
Tourism is a general phenomenon that arises from the fact that the natural, historical and other attractions which are supported by the infrastructure and superstructure facilities and presented to consumers. Because of this reason, ability of attractions to continue of offering tourist products and increasing their tourism potential depends on the sustainability of tourism. Sustainability of tourism activities in a region is highly depend on the stakeholder's attitudes towards sustainability. University students could be seen as an important stakeholder with their potential of shaping the tourisms future due to their high level of travel intentions and participation in tourism, as well as the education they receive and the social status they will reach in the future. The aim of this study is to measure the attitudes of university students about tourism sustainability. According to this aim, the research is planned as a descriptive study which is included in quantitative research. In this study, Suk et al., (2005) scale was used which has 38 items and 7 dimensions for measuring local population's sustainable tourism attitudes. Primary data sources were used in the study. In order to measure the attitudes of participants about tourism sustainability, a questionnaire form was prepared and made by face to face technique. Students of Mehmet Akif Ersoy University which is located in Burdur where a wide variety of alternative tourism types has been the participants of the research. In the study, the department of students, their holiday experiences, the average holiday time, the type of hotel generally occupied, the average monthly expenditure amount, life period in Burdur, their gender and seven dimensions of tourism sustainability attitudes are investigated by the results of the factor analysis. Hypothesis tests, correlation and cluster analysis were also used in this study. Finally, at the end of the study, it was found that there is a relationship between the university students' department, the type of accommodation, holiday period, gender and tourism sustainability attitudes.
\end{abstract}

Keywords: Tourism, Sustainability, University Students.

Received: 08.10.2019

Accepted: 15.01 .2020

Suggested Citation:

Kilinç, O., Kilinç, U. and Ongun, U. (2020). University Students' Attitudes towards Sustainable Tourism: The Case of Mehmet Akif Ersoy University, Journal of Turkish Tourism Research, 4(1): 67-84.

(C) 2020 Türk Turizm Araştırmaları Dergisi. 


\section{GİRIŞ}

Turizm genel olarak gerçekleştirildiği çevredeki doğal, tarihi ve diğer çekiciliklerin alt ve üst yapı olanakları ile birlikte desteklenerek tüketicilere sunulması ile ortaya çıkan bir olgudur. Bu nedenle çekim yerlerinin turistik ürünlerini sunmaya devam edebilmesi ve turizm potansiyellerini arttırabilmesi her şeyden önce turizmin sürdürülebilirliğine bağlıdır. Bir bölgede turizmin sürdürülebilir olması paydaşların sürdürülebilirlik tutumlarına yüksek oranda bağlıdır. Turizm sektörü, diğer sektörler arasında sürdürülebilirlik kavramının tanımını ve ilkelerini belirleyerek faaliyet planı içerisinde yerleştiren ilk sektörlerdendir (Budeanu vd., 2015). Sürdürülebilirliğin kalkınma açısından önemi anlaşılmaya başlanması ile beraber sektörler kendi içerisinde konusu ile ilintili sürdürülebilirlik çözümü yaratmaya başlamışlardır.

Sürdürülebilir turizm başarılı bir şekilde uygulandığında yerel halkın yaşam kalitesi gelişir. Bu durum turizm faaliyetleri ile beraber ek mesleklerin gelişmesi, ekonomik faydanın artması, yerel halka ek gelir kaynakları sağlaması ile ilişkilendirilmektedir (Jurowski ve Gürsoy, 2004). Yerel halka katkısı yüksek olan sürdürülebilir turizm anlayışı konusunda turizme katılma potansiyeli bir hayli yüksek olan öğrencilerin tutumlarının belirlenmesi bölge açısından etkili bir sürdürülebilir turizm planlaması yapılabilmesi açısından oldukça önemlidir. Üniversite öğrencileri bir yandan seyahat etme ve turizme katılma düzeylerinin yüksekliği ile turist olarak, diğer yandan turizm eğitimi alan öğrenciler başta olmak üzere aldıkları eğitim ve gelecekte ulaşacakları sosyal statü nedeni ile turizm geleceğini şekillendirme potansiyelleri ile önemli paydaşlar olarak görülmelidir. Üniversite öğrencilerinin sürdürülebilir turizme yönelik tutumlarının ortaya konması turizmin geleceğine yönelik bir öngörü ortaya koyacaktır.

Araştırmada bir yandan turizm faaliyetlerine katılma potansiyeli yüksek olan üniversite öğrencilerinin ve gelecekte turizm çalışanı ve yöneticisi olma potansiyeli yüksek olan turizm bölümü öğrencilerinin sürdürülebilir turizme yönelik tutumları ortaya konmaya çalışılmıştır. Konu ile ilgili olarak geçmiş dönemde yapılmış çalışmalarda örneklem grubu içerisinde öğrencilere yer verilse de, başlı başına üniversite öğrencilerinin tutumlarını ölçen bir çalışmaya rastlanmamıştır. Çalışma bu nedenle turizm hareketlerine turist olarak katılma potansiyeli yüksek, eğitimli ve geleceğin yöneticileri olmaya aday bir grubun sürdürülebilir turizme yönelik tutumlarını ölçerek literatürdeki boşluğu doldurmaya adaydır. Diğer yandan araştırmada sürdürülebilir turizm politikaları ile desteklenmesi gereken birçok alternatif turizm potansiyeline sahip Burdur bölgesi için turizmi şekillendirebilecek önemli bulgulara ulaşılması amaçlanmaktadır. Bu sayede Burdur turizminin geliştirilmesi ve sürdürülebilirliğinin sağlanması için gerekli ön bilgiler edinilerek literatüre katkı yapılması amaçlanmaktadır. Bu amaç doğrultusunda araştırma kavramsal çerçeve, araştırmanın metodolojisi, bulgular, sonuç ve öneriler kısmından oluşmaktadır.

\section{KAVRAMSAL ÇERÇEVE}

\section{Sürdürülebilirlik Kavramı ve Gelişim Süreci}

Sürdürülebilirlik kavramını 18. ve 19. yüzyıl iktisatçıları Malthus ve Levons'e kadar götürmek mümkün olsa da, sürdürülebilirlik ilk kez 1980 Mart'ında yayınlanan Dünya Koruma Stratejisi ile kamuoyunun dikkatini çekmiştir (Kuter ve Ünal, 2009). Bu kavram üzerinde çalışma yapan farklı bilim dalları farklı yaklaşımlar ve tanımlar geliştirmişlerdir. İktisatçlar, yaşam standartlarının belli bir düzeyde korunması gerekliliğini vurgulamışlar, çevrebilimciler biyo-çeşitlilik ve çevre bilimsel esneklik yönüyle ilgilenmişler, sosyologlar da topluluklar içindeki sosyolojik bağların ve karşılıklı ilişkilerin korunması gereksinimine değinmişlerdir (Yeni, 2014). Aslında sürdürülebilirlik, belirli bir sistemin kesintisiz ve bozulmadan, aşırı tüketim yapılmadan, ana kaynaklara fazla yüklenmeden devamlılığın sağlanması ve bu çerçevede koruma bilincinin ön planda tutulmasını içermektedir (Kaypak, 2010). Sürdürülebilirlik, bireyin kendi yaşamını sağlarken sınırlı kaynakları yok etmeden, tüm kaynaklara saygılı ve koruyarak da gelişmesinin mümkün olabileceği mantığını kavraması gerekmektedir (Sonuç, 2014). 
1970'li yılların sonunda 1980'li yılların başında turizmin gelişmesiyle birlikte ortaya çıkan negatif etkiler turizm kavramı tartışmalarını gündeme getirmiş (Çelik ve Bahar, 2014) ve bu yıllarda olgunlaşan çevrecilik akımı sürdürülebilirliği, kalkınma ile beraber ele alarak desteklenmesini arttırmıştır (Yeni, 2014). Sürdürülebilir kalkınma, insan ihtiyaçları ile doğal kaynaklar arasında bir denge kurularak, kaynakların kullanımında geleceğe uyumlu bir planlama yapılmasını amaçlayan bütünsel bir yaklaşımdır (Kulaç ve Mutlu Çamoğlu, 2015). Sürdürülebilir turizm sürdürülebilir kalkınmaya dayanmaktadır (Hardy ve Beeton, 2009).

\section{Sürdürülebilir Turizm}

Turizm sektöründe sürdürülebilirlik 1990'ların başında sürdürülebilir turizm kavramı olarak isimlendirilmiştir. Sonrasında 5. Toplumsal Çevre ve Sürdürülebilir Gelişme Programında sürdürülebilir turizm öncelikli alan olarak belirlenmiştir (Weaver, 2008). Bu durum sektör için çevrenin özel öneminden kaynaklanmaktadır.

Turizm gelişimi toplulukların sosyal yapılarında değişiklikler meydana getirmektedir. Planlama sürecinin doğru yapılamaması, yerel değerleri önemsemeyen ve çevre ile uyumu göz ardı eden bir çerçevede gerçekleşen turizm gelişimi, yerel halkın sosyal, kültürel ve ekonomik bağlamda zarar görmesine neden olmaktadır. Turizm gelişiminin sürdürülebilir olması, bireylerle ve yerel değerlerle uyumluluğun sağlanması ancak yerel halkın algı ve tutumunun dikkate alınması ile mümkündür (Sheldon ve Abenoja, 2001). Diğer bir ifadeyle temel nokta yerel halk olmalıdır (Suk vd., 2005).

Sürdürülebilir turizm "yerli halkın yaşam kalitesini arttıran, ziyaretçilerin deneyim kalitesini güçlendiren, ziyaretçilerin ve yerli halkın çevre kalitesini sürdürmesini hedefleyen bir alternatif turizm formu" olarak tanımlanmaktadır. Daha geniş bir bakış açısıyla sürdürülebilir turizm, kitle turizmin negatif etkilerini onarmanın en iyi yolu olarak görülmektedir (Suk vd., 2005). Sürdürülebilir turizm ayrıca, turist memnuniyeti seviyesini korumalı, turistlerin sürdürülebilirlik konusunda farkındalığını arttırmalı ve sürdürülebilir turizm uygulamalarını pazarlarken onlara anlamlı bir deneyim garanti etmelidir (Sonuç, 2014).

Glasson ve arkadaşlarına (1995) göre turizm ziyaretçilerin deneyim yaşamak için geldikleri çevreyi fazla zarar vererek kendi kendini öldürebilecek yıkımın tohumlarını bünyesinde taşır. Doğal çevre kaynaklarını talep öğesine dönüştüren turizm sektörünün kitlesel gelişimi, kıyı bölgesinin çirkin görüntüsü, kanalizasyon ve çöp sorunu gibi problemleri oluşturabileceğinden sektörün geleceğinin sürdürülebilir turizm kavramı çerçevesinde şekillenmesi beklenir (Can, 2013).

Turizm sektöründe sürdürülebilirlik üç temele dayandırılmaktadır. Bu temellerden ilki turizm ile doğal ve kültürel çevre arasında sıkı bağların bulunduğu ve çevrenin turist açısından bir çekim yeri olduğudur. İkinci temel ise çevresel etmenlerin turizm üzerinde etkide bulunması unsurudur. Turizm sektörü ve sürdürülebilirlik kavramı ile ilgili üçüncü temel turizmin bizzat çevreye etkilerin anlaşılması üzerine kurulmuştur. Bütün bu temellere paralel olarak sürdürülebilir turizm kavramının üç temel dayanağı oluşturulmuştur. Bunlardan birincisi turizmin çevresel olarak düşük bir etkiye sahip olduğu hatta çevreye olan zararı minimize eden bir sektör olduğu yönündedir. İkinci dayanak sürdürülebilir turizmin toplumun sosyal ve kültürel yapısına zarar vermediği ile ilgilidir. Üçüncüsü sürdürülebilir turizmin yerel halka yarattığı sürdürülebilir ve adil gelir ile ekonomik kalkınmaya katkısıdır (Yılmaz vd., 2015). Sürdürülebilir turizmin ilk dayanağı olarak görülen turizm ve doğal ve kültürel çevre arasındaki bağlantı turistik ürünlerin temelinde çevre faktörlerinin ve kültürel ürünlerinde yer almasıdır. Mağaralar, şelaleler gibi çevre güzellikleri aynı zamanda turistler için bir çekim unsuru olarak görüldüğünden turizm devamlılığı için korunması gereklilik olarak görülmektedir. İkinci dayanak olarak görülen turizm ve kültür ilişkisi içinde benzer durum söz konusudur. Bir bölgenin kültürel yapısı turistler için bir çekicilik olabilir ve korunması bir gereklilik haline gelebilir. Üçüncü temel madde olarak görülen turizm sektörünün yerel halkın gelir düzeyine olumlu katkısı ise diğer iki unsurdan farklı değerlendirilebilir. Bu unsur turizmin bölgesel kalkınma sürecine etkisinin yüksek 
olması ile bağlantılıdır. Turizm sektörünün yapısı gereği destinasyona turistin gelmesinin gerekliliği doğrultusunda bölge halkının doğrudan turizmden para kazanma şansı bulunmaktadır ve bu durum bölgesel kalkınma sürecinde bölgelere eşit kalkınma fırsatlarının sunulması açısından önemli bir avantaj olarak görülmektedir. Turizmin bölgesel kalkınmadaki pozitif etkisi bilinmekle beraber ekosisteme verdiği olumsuzluklar konunun tartışılan boyutudur. Bu yüzden turizmin sürdürülebilirlik kavramı ile beraber yürütülmesi önerilen bir durumdur (Durlu Özkaya vd., 2013).

\section{Üniversite Öğrencileri ve Turizm Sürdürülebilirliği İlişkisi}

Turizm sürdürülebilirliği çekim yerleri açısından turizm hareketlerinin devam edebilmesi ve süreklilik gösterebilmesi için önem taşımaktadır. Turistlerin turistik ürün tüketicileri olarak turizmin sürdürülebilirliğine yönelik tutum ve davranışları turistik değerlerin sürekliliğini doğrudan etkileyecektir. Üniversite öğrencileri bir yandan turizm hareketlerine yoğun olarak katılan turistler olarak turistik ürünlerin önemli kullanıcıları iken, diğer yandan başta turizm eğitimi alan öğrenciler olarak gelecekte üretici veya yönetici olarak turizm sürdürülebilirliğine yönelik kararlar alabilme potansiyeli yüksek bir grup olarak görülmektedir. Bu nedenlerle üniversite öğrencilerinin turizm sürdürülebilirliğine yönelik tutumlarının ölçülmesi turizmin sürdürülebilirliği açısından büyük önem taşımaktadır.

Üniversite öğrencileri her ne kadar genç nüfus olarak görülse de yaş, sosyo-kültürel, eğitim ve ekonomik özellikleri ile içinde bulundukları genel toplumdan farklılıklar göstermektedir (Davies ve Lea, 1995). Bu durumun yanı sıra tam zamanlı çalışma imkanı bulan genç nüfus ile farklı düşünce yapısı ve imkanlara sahip üniversite öğrencileri aynı kalıp içerisinde ele alınmamalıdır (Pritchard ve Morgan, 1996). Genç nüfus ile üniversite öğrencileri özellikleri açısından kıyaslandığında araştırmalarda üniversite öğrencilerinin tatil davranışlarının daha öncelikli olarak ele alınması gerektiği görülmektedir (Carr, 2005). Tatile çıkma davranışı söz konusu olduğunda, ekonomik ve zamansal şartlar ile güdülenme üniversite öğrencilerinde diğer genç nüfusa oranla daha belirleyici unsurlar olmaktadır (Davies ve Lea, 1995). Üniversite öğrencileri arasında tam zamanlı çalışma durumu pek mümkün olmadığından gelirleri daha düşüktür. Ancak genelde üniversite öğrencilerinin çok az bağlayıcıları ve bir yıl içerisinde 20 haftaya yakın serbest zamanları vardır. Ayrıca üniversite çevresi bireyleri seyahat etme ve tatil yapma konularında özendirmektedir (Smeaton vd., 1998). 1990'lı ylllarda genel olarak gelir durumu düşük olmasına rağmen uluslararası gezginlerin $\% 20$ 'sini üniversite öğrencileri oluşturmaktadır (Bywater, 1993). Zamanımızda ve gelecekteki üniversite öğrenci nüfusu düşünüldüğünde, üniversite öğrencileri turizm endüstrisi için önemli bir pazar olarak görülmelidir (Carr, 2005). Günümüzde gençlerin turizm hareketlerine katılımı ile ilgili yapılan çalışmalar genelde 15-24 yaş aralığını kapsayan gençlik turizmi kapsamında incelenmektedir. Genç turizm pazarı turizm genel pazarı içerisindeki yerini her geçen gün arttırmaktadır. Öyle ki 2020 yılında genç turizm pazarının 300 milyon kişiye ulaşması öngörülmektedir (Khan, 2019). Yukarıdaki bilgiler ışığında öğrencilerin turizme katılma potansiyellerinin bir hayli yüksek olduğu anlaşılmaktadır. Bu durumun yanı sıra turizm alanında eğitim alan öğrenciler geleceğin yöneticileri ve işgörenleri olarak görülmektedir. Turizm öğrencilerinin bakış açılarının dikkate alınması sektörün şekillenmesi ve çeşitlenmesi açısından önem arz etmektedir (Ayaz vd., 2012; Ongun vd., 2016).

Turizm sürdürülebilirliği ile ilgili olarak akademik yazında birçok çalışma bulunmaktadır. Bu çalışmalardan makaleler kırsal turizm ve alternatif turizm konuları ile daha sık ilişkide olup, örneklem genelde yerel halk, turistler ve bilirkişilerden seçilmiştir. Tez çalışmalarında ise çalışmaların daha çok destinasyon yönetimi ve planlaması, turizm gelişimi, konaklama işletmeleri, ziyaretçi tutumları, yerel halk tutumları, sivil toplum kuruluşlarının rolü, turizm politikaları, çevreye duyarlılık ve eko-turizm konuları ile ilişkilendirildiği görülmektedir. Yine tez çalışmalarında da örneklem olarak genelde turistler, yerliler ve bilirkişiler seçilmiştir (Güdü Demirbulat ve Tetik Dinç, 2017).

Konu ile ilgili akademik literatür genel olarak ele alındığında üniversite öğrenciler gelirleri doğrultusunda turizme katılımı yüksek olan bir turist tipi olarak görülmektedir. Araştırmalarda turizm 
sürdürülebilirliği ile ilgili olarak turist tutumları ve bakış açılarını konu alan çalışmalar bulunmaktadır. Söz konusu çalışmalara konu olan turistler içerisinde örneklem olarak her ne kadar öğrenciler yer alsa bile, turizm hareketlerine katkısı açısından başlı başına üniversite öğrencilerin tutum ve davranışlarını ele alan bir çalışmaya rastlanmamıştır. Turizme katılım potansiyelleri göz önüne alındığında üniversite öğrencilerinin sürdürülebilir turizme yönelik tutumları turizmin sürdürülebilirliği açısından önem taşımaktadır. Diğer yandan turizme turist olarak katılım potansiyelleri ötesinde, turizmi gelecekte şekillendirmesi ve çeşitlendirmesi beklenen turizm eğitimi alan üniversite öğrencilerinin sürdürülebilir turizme yönelik tutumları, sürdürülebilir turizm faaliyetlerinin yoğunluğunu ve şeklini de gelecekte belirlemesi açısından büyük öneme sahiptir.

\section{ARAŞTIRMANIN METODOLOJİSI}

\section{Araştırmanın Amacı ve Yöntemi}

Araştırmanın amacı sürdürülebilir turizm politikaları ile desteklenmesi gereken birçok alternatif turizm potansiyeline sahip Burdur bölgesi için turizmi şekillendirebilecek önemli bulgulara ulaşılmasıdır. Bu amaç doğrultusunda çalışma, betimleyici yani durum saptayıcı bir araştırma olarak planlanmıştır. Suk ve arkadaşları (2005) tarafından geliştirilen 38 ifadeden oluşan 7 boyutlu yerel halkın sürdürülebilir turizm tutumlarını ölçmek için kullandıkları ölçek kullanılmıştır. Bu ölçüm aracı Türkçe'ye çevrilmiş, iki akademisyen tarafından tekrar İngilizce çevrilerek ölçeğin dilbilgisi tutarlılığı sağlanmıştır. Ölçekte yer alan tutum kategorileri "1 kesinlikle katılmıyorum - 5 kesinlikle katılıyorum" şeklinde beşli Likert derecelenmesine göredir. Ölçeğin Crombach Alfa iç tutarlılık katsayısı 0,89 olarak bulunmuştur.

Araştırmanın genel evrenini teşkil eden Mehmet Akif Ersoy Üniversitesi 11 Fakülte, 6 Yüksekokul ve 13 Meslek Yüksekokulu ile faaliyet göstermektedir. Burdur merkez ve ilçelerdeki yaşam şartları farklılıkları, fen bilimleri ve sosyal bilimler eğitim alanlarındaki temel farklılıklar, maddi ve zaman sinırlılıkları gibi unsurlar göz önüne alınarak araştırma evreni üniversite merkez kampüsünde faaliyet gösteren sosyal bilimler alanında eğitim veren okullar ile sınırlandırılmıştır. Örneklem açık olan bölümlerin öğrencisi olmaması, öğrencilerin işbaşı eğitiminde olması ve ulaşılabilirlik gibi nedenlerle Fen Edebiyat Fakültesi, Eğitim Fakültesi ve Turizm İşletmeciliği ve Otelcilik Yüksekokulu öğrencilerinden oluşmaktadır. Üniversite genelinde önlisans programında 12683, lisans programlarında 17.442 kayıtlı öğrenci bulunmaktadır. Araştırma kapsamına dahil edilen bölüm sayısı dört tanedir. Araştırmacılar, bizzat birimlere giderek anket uygulamasını gerçekleştirmişler ve toplam 671 katılımcıya ulaşılmıştır. Katılımcılardan geri dönen soru formlarından 40 tanesi soruların cevaplanmaması ve cevapların güvenirliğinin düşük olması nedenleri ile değerlendirmeye katılmamıştır. Toplamda 631 soru formundan elde edilen veriler araştırmaya dahil edilmiştir.

Katılımcların sadece üniversite öğrencilerinden oluşması araştırmanın sınırlılı̆̆ını oluştururken, araştırma konusu itibariyle bir gerekliliktir. Bölgenin turizm planlama sürecinde temel paydaşlardan birisi olan Mehmet Akif Ersoy Üniversitesinin öğrencilerinin sürdürülebilir turizm algıları planlama sürecinde önemli veriler içereceğinden ve belirleyici olacağından konu öğrencilerin tutumları ile sınırlanmıştır.

\section{Güvenirlik ve Geçerlilik}

Araştırmada birincil veri kaynakları kullanılmıştır. Araştırma verilerinin toplanmasında katılımcıların turizm sürdürülebilirliği üzerine tutumlarını ölçmeye yönelik olarak bir soru formu düzenlenmiş ve soru formları yüz yüze görüşme tekniği ile cevaplandırılarak araştırma verileri elde edilmiştir. Araştırmanın ölçüm aracı Suk ve arkadaşlarının 2005 yılında yaptığı çalışmada kullanılan ölçeğin Türkçe'ye çevrilmesi ile oluşturulmuştur. Daha önce uyarlanmış bir ölçeğin kullanılması ile ölçümün güvenirliği artmaktadır (Karakoç ve Dönmez, 2014). Uyarlama çalışmasında ölçeğin çevirisi konusunda uzmanlığını ispatlamış mütercim tercümanlık belgesine sahip iki İngilizce öğretim görevlisine önce 
İngilizce'den Türkçe'ye, sonrasında Türkçe'den tekrar İngilizce'ye çevrilmesi ve sonrasında konu ile ilgili uzmanlık seviyesi doktora düzeyinde olan ve İngilizce bilgisi belgelerle ispatlanabilir uzman görüşü alınarak gerçekleştirilmiştir. Orijinal ölçeğin güvenirlik ölçümü açısından Cronbach alfa katsayısı 0,87'dir. Araştırmada kullanılan uyarlanmış ölçeğin Cronbach alfa katsayısı 0,89 olarak bulunmuştur. Cronbach alfa güvenirlik katsayısının kabul edilebilir olma sınırı 0,70 olarak gösterilmektedir. Uyarlanacak ölçeğin yüksek bir güvenirlik ve geçerliğe sahip olması durumunda, uyarlanan ölçeğin de bu değerlere yakın değerler vermesi beklenir (Karakoç ve Dönmez, 2014). Bu bağlamda Cronbach alfa katsayılarına göre uyarlanan ölçek güvenilirdir. Tablo 1'de görüldüğü üzere Alfa Güvenirlik Katsayısı (Cronbach's Alpha) ile İlgili Soru Çıkarıldığında Elde Edilen Alfa Katsayısı (Cronbach's Alpha Based on Standardized Items) değerleri birbirine oldukça yakındır. Bu durum ölçekte yer alan soruların hiçbirinin çıkartılmasına gerek olmadığını göstermektedir (Kalaycı, 2005). Sorular arası varyans analizi anlamlılık düzeyi değeri ölçümler arasında farklılık olduğunu göstermektedir $(\mathrm{P}<, 05)$. Hotelling's $\mathrm{T}$ kare testi sonuçları soru ortalamaları arasındaki farklılı̆̆ın anlamlı olduğunu göstermektedir $(\mathrm{P}<, 05)$. Güvenirlik analizi sonucunda elde edilen veriler ölçümün güvenilir olduğunu göstermektedir.

Tablo 1: Güvenirlik Analizi Verileri

\begin{tabular}{|l|c|c|}
\hline & Madde Sayısı & Değer \\
\hline Alfa Güvenirlik Katsayısı & 38 & 0,890 \\
\hline İlgili Soru Çıkarıldı̆̆ında Elde Edilen Alfa Katsayısı & 38 & 0,899 \\
\hline Sorular Arası Varyans Analizi Anlamlılık Düzeyi (Sig.) & 38 & 0,000 \\
\hline Hotelling's T Kare Testi Anlamlılık Düzeyi (Sig.) & 38 & 0,000 \\
\hline
\end{tabular}

\section{Normallik Testleri}

Araştırmada hipotez ve ilişki testleri yapılmadan önce istatistiki olarak uygun testlerin yapılabilmesi için verilerin normalliğinin incelenmesi gerekmektedir. Verilerin normalliği basıklık-çarpıklık katsayılarına bakılarak incelenebildiği gibi, Kolmogorov-Simirnov ve Shapiro Wilk testleri ile de incelenebilmektedir (Kalaycı, 2005). Araştırmada veri sayısı 30'dan büyük olduğu için normallik incelemesinde Kolmogorov-Simirnov testi kullanılmıştır. Araştırma hipotezlerine göre normallik testi sonuçlarına göre veriler normal dağılım göstermemektedir. Faktör analizinin uygulanabilmesi açısından veriler normal dağılıma uymamakla birlikte araştırmanın örneklem sayısının (631) 30'dan büyük olması nedenli ile merkezi limit teoremine göre faktör analizi yapabilmek için normallik ön şartı aranmamıştır (Gosling, 2004; 64).

Tablo 2: Normallik Verileri

\begin{tabular}{|l|l|c|c|}
\hline Bağımsız Değişken & \multicolumn{1}{|c|}{ Bağımlı Değişken } & Frekans & Anlamlılık Düzeyi (Sig.) \\
\hline Eğitim Görülen Bölüm & Tatmine Dayalı Başarı Planlaması & 631 & 0,000 \\
\hline Eğitim Görülen Bölüm & Ekonomik Fayda & 631 & 0,000 \\
\hline Eğitim Görülen Bölüm & Toplumsal Çevre & 631 & 0,000 \\
\hline Eğitim Görülen Bölüm & Doğal çevre ve tabiat & 631 & 0,000 \\
\hline Eğitim Görülen Bölüm & Sosyal Maliyet & 631 & 0,000 \\
\hline Eğitim Görülen Bölüm & Büyüme Maliyeti & 631 & 0,000 \\
\hline Eğitim Görülen Bölüm & Turizmin yerlilere etkisi & 631 & 0,000 \\
\hline Cinsiyet & Tatmine Dayalı Başarı Planlaması & 631 & 0,000 \\
\hline Cinsiyet & Ekonomik Fayda & 631 & 0,000 \\
\hline Cinsiyet & Toplumsal Çevre & 631 & 0,000 \\
\hline Cinsiyet & Doğal çevre ve tabiat & 631 & 0,000 \\
\hline
\end{tabular}


Türk Turizm Araştırmaları Dergisi, 4(1): 67-84.

\begin{tabular}{|l|l|c|c|}
\hline Cinsiyet & Sosyal Maliyet & 631 & 0,000 \\
\hline Cinsiyet & Büyüme Maliyeti & 631 & 0,000 \\
\hline Cinsiyet & Turizmin yerlilere etkisi & 631 & 0,000 \\
\hline Deneyim & Tatmine Dayalı Başarı Planlaması & 631 & 0,000 \\
\hline Deneyim & Ekonomik Fayda & 631 & 0,000 \\
\hline Deneyim & Toplumsal Çevre & 631 & 0,000 \\
\hline Deneyim & Doğal çevre ve tabiat & 631 & 0,000 \\
\hline Deneyim & Sosyal Maliyet & 631 & 0,000 \\
\hline Deneyim & Büyüme Maliyeti & 631 & 0,000 \\
\hline Deneyim & Turizmin yerlilere etkisi & 631 & 0,000 \\
\hline Deneyim Türü & Tatmine Dayalı Başarı Planlaması & 631 & 0,000 \\
\hline Deneyim Türü & Ekonomik Fayda & 631 & 0,000 \\
\hline Deneyim Türü & Toplumsal Çevre & 631 & 0,000 \\
\hline Deneyim Türü & Doğal çevre ve tabiat & 631 & 0,000 \\
\hline Deneyim Türü & Sosyal Maliyet & 631 & 0,000 \\
\hline Deneyim Türü & Büyüme Maliyeti & 631 & 0,000 \\
\hline Deneyim Türü & Turizmin yerlilere etkisi & 631 & 0,000 \\
\hline Harcama Miktarı & Tatmine Dayalı Başarı Planlaması & 631 & 0,000 \\
\hline Harcama Miktarı & Ekonomik Fayda & 631 & 0,000 \\
\hline Harcama Miktarı & Toplumsal Çevre & 631 & 0,000 \\
\hline Harcama Miktarı & Doğal çevre ve tabiat & 631 & 0,000 \\
\hline Harcama Miktarı & Sosyal Maliyet & 631 & 0,000 \\
\hline Harcama Miktarı & Büyüme Maliyeti & 631 & 0,000 \\
\hline Harcama Miktarı & Turizmin yerlilere etkisi & 631 & 0,000 \\
\hline Konaklama Süresi & Tatmine Dayalı Başarı Planlaması & 631 & 0,000 \\
\hline Konaklama Süresi & Ekonomik Fayda & 631 & 0,000 \\
\hline Konaklama Süresi & Toplumsal Çevre & 631 & 0,000 \\
\hline Konaklama Süresi & Doğal çevre ve tabiat & 631 & 0,000 \\
\hline Konaklama Süresi & Sosyal Maliyet & 631 & 0,000 \\
\hline Konaklama Süresi & Büyüme Maliyeti & 631 & 0,000 \\
\hline Konaklama Süresi & Turizmin yerlilere etkisi & 631 & 0,000 \\
\hline & & & \\
\hline
\end{tabular}

\section{BULGULAR}

Araştırma sürecine dahil edilen katılımcıların demografik özelliklerine ait frekans sayıları Tablo 3'de verilmektedir.

Tablo 3 incelendiğinde örneklemin \% 61,3'ü kadın, \% 37,6's1 erkektir. Katılımcıların \% 58,6'sı Turizm İşletmeciliği ve Otelcilik Yüksekokulu Konaklama bölümü öğrencisidir. Verilerden son tatilde konaklanan işletme türü sorusunda kayıp veri sayısı yüksek olması ilgi çekici olarak görülse de bu durumun nedeni, aslında tatil deneyimi olmayanların bu seçeneği işaretlememesidir. Katılımcıların yılda ortalama 11 günü tatilde bir konaklama işletmesinde geçirdiği, aylık ortalama yaklaşı $902 \mathrm{TL}$ harcama yaptıkları görülmektedir. Katılımclar ortalama olarak yaklaşık 25 aydan beri Burdur'da yaşamaktadırlar. Katılımcıların yarısından fazlasının birinci ve ikinci sınıf öğrencilerinden oluştuğu düşünüldüğ̈̈nde bu durum normaldir.

Üniversite öğrencilerinin turizm sürdürülebilirliğine yönelik tutumlarına yönelik ifadelere alt boyutlar halinde sunabilmek için veriler faktör analizine tabi tutulmuştur faktör analizi yapılabilmesi için yapılan uygunluk değerlemelerine göre Barlett testi anlamlılık seviyesine göre (Sig.0,000<0,05) değişkenler arasında yüksek korelasyon olduğu, bir başka deyişle veri setinin faktör analizi için uygun olduğu görülmüştür. Kaiser-Meyer-Olkin örneklem yeterliliği ölçütü katsayısı 0,916 bulunmuştur. Bu 
değerin 0,90 üzerinde olması veri setinin faktör analizi uygulanabilmesi için mükemmel özellik taşıdığını göstermektedir (Sharma, 1996: 116).

Tablo 3: Örnekleme Ait Tanımlayıcı İstatistikler

\begin{tabular}{|c|c|c|c|c|}
\hline & & \multicolumn{3}{|c|}{ Katılımcı Sayısı } \\
\hline & & Geçerli (f) & Kayıp (f) & Toplam (f) \\
\hline \multirow[t]{2}{*}{ Cinsiyet } & Kadın & 387 & \multirow[t]{2}{*}{7} & \multirow[t]{2}{*}{631} \\
\hline & Erkek & 237 & & \\
\hline \multirow[t]{4}{*}{ Bölüm } & Konaklama & 370 & \multirow[t]{4}{*}{0} & \multirow[t]{4}{*}{631} \\
\hline & Antropoloji & 47 & & \\
\hline & Sosyoloji & 129 & & \\
\hline & $\begin{array}{l}\text { Sosyal Bilgiler } \\
\text { Öğretmenliği }\end{array}$ & 85 & & \\
\hline \multirow[t]{4}{*}{ Sinif } & Bir & 170 & \multirow[t]{4}{*}{146} & \multirow[t]{4}{*}{631} \\
\hline & İki & 177 & & \\
\hline & $\ddot{U} \ddot{U}_{c ̧}$ & 114 & & \\
\hline & Dört & 23 & & \\
\hline \multirow{2}{*}{$\begin{array}{l}\text { Tatil } \\
\text { Deneyimi }\end{array}$} & Var & 393 & \multirow[t]{2}{*}{34} & \multirow[t]{2}{*}{631} \\
\hline & Yok & 204 & & \\
\hline \multirow{8}{*}{$\begin{array}{l}\text { Son Tatilde } \\
\text { Konaklanan } \\
\text { İşletme Türü }\end{array}$} & Beş Yıldiz Otel & 153 & \multirow[t]{8}{*}{224} & \multirow[t]{8}{*}{631} \\
\hline & Dört Yildız Otel & 38 & & \\
\hline & Üç ve Altı Yıldız Otel & 19 & & \\
\hline & Pansiyon & 51 & & \\
\hline & Tatil Köyü & 46 & & \\
\hline & Apart Otel & 55 & & \\
\hline & Butik Otel & 31 & & \\
\hline & Diğer* & 14 & & \\
\hline \multicolumn{2}{|c|}{$\begin{array}{l}\text { Yılda ortalama konaklama İşletmesinde } \\
\text { Geçirilen Gün Sayısı }\end{array}$} & 345 & 286 & 631 \\
\hline \multicolumn{2}{|c|}{ Aylık Ortalama Harcama } & 466 & 165 & 631 \\
\hline \multicolumn{2}{|c|}{ Burdur'da Yaşama Süresi } & 443 & 188 & 631 \\
\hline
\end{tabular}

*Diğer cevabı altında katılımcılar ikincil konut, çadır, belediye belgeli işletme ve tanıdık-akraba yanında cevaplarını vermişlerdir.

Tablo 4: Öğrencilerin Turizm Sürdürülebilirliğine Yönelik Tutumlarını İçeren Faktör Analizi

\begin{tabular}{|c|c|c|c|c|c|c|c|}
\hline & \multicolumn{7}{|c|}{ Faktör Grupları } \\
\hline & 1 & 2 & 3 & 4 & 5 & 6 & 7 \\
\hline Turizm işletmeleri ziyaretçilerin tatminlerini takip e & 675 &, 222 &,- 009 & 248 &, 024 &,- 040 & 195 \\
\hline $\begin{array}{l}\text { Gelişmiş planlama strat } \\
\text { planlanabileceğine inan }\end{array}$ & 670 & ,208 & 191 & 087 &,- 090 & 151 &,- 039 \\
\hline $\begin{array}{l}\text { Turizm yatırımları gelecekteki ziyaretçilerin kaliteli turizm } \\
\text { deneyimleri yaşamlarını sağlar }\end{array}$ & 663 & ,287 &, 189 & 133 &,- 053 & 005 & ,063 \\
\hline $\begin{array}{l}\text { ki ziyaretçilerin ihtiyaçlarını } \\
\text { amaktadır }\end{array}$ & 659 & ,153 & 116 & 153 &,- 035 & 018 & 135 \\
\hline un dönemli bir bakış açısına & ,654 & ,228 & ,038 & 185 &,- 068 &,- 062 & 140 \\
\hline Turizm yatırımları geleceği düşünerek planlanır & ,628 & ,139 & ,366 & ,009 &,- 046 & ,143 &,- 063 \\
\hline $\begin{array}{l}\text { Toplumsal çekicilikler ziyaretçiler için kusursuz en temel } \\
\text { üründür }\end{array}$ &, 581 & , 2 & -0 & 167 & ,036 & , 034 & , 084 \\
\hline
\end{tabular}




\begin{tabular}{|c|c|c|c|c|c|c|c|}
\hline $\begin{array}{l}\text { Turizm yatırımları toplumu geliştiren fonlara kaynak } \\
\text { ayırmalıdır }\end{array}$ & ,549 & ,224, & ,019, & 193 &, 049 & $\mid-, 069$ & 363, \\
\hline Turizm sektörü toplumun tüm değerlerini benimser & 475 & ,109, & 400 &,- 099 & ,030 & ,185 &,- 017 \\
\hline Turizm yerel ekonomiyi çeşitlendirir & ,273 & ,685, & ,160 & 205 &,- 092 & , 044 & 101 \\
\hline Turizm yeni vergi gelirleri yaratır & 103 & ,675- &,- 037 & 130 & ,150 & ,048 &, 037 \\
\hline Turizm yerli ürünler için yeni bir pazar yaratır & 310 & 674, & ,208 & 183 &,- 076 &,- 013 & 177 \\
\hline $\begin{array}{l}\text { Turizmin ekonomimiz için iyi, geliştirici bir sektör olduğunu } \\
\text { düşünüyorum }\end{array}$ & ,341 & ,668 & ,116 & 167 & -,088 & 035 &,- 014 \\
\hline Turizm toplum için güçlü bir ekonomik katkı sağlayıcıdır & ,339 & ,648 & , 056 & 238 &,- 079 & , 128 & 073 \\
\hline Turizm toplumdaki diğer sektörleri olumlu etkiler & 265 & ,623 & ,294 & ,136 &,- 145 &,- 015 & 174 \\
\hline Turizmi gelir getirmesinden dolayı seviyorum & , 169 & ,543 & ,045 & , 026 & 241 & 140 &,- 107 \\
\hline $\begin{array}{l}\text { Turizm ile ilgili kararlar toplum üyelerinin hepsinin katılımı } \\
\text { ile gerçekleşmektedir }\end{array}$ & 243 & ,410, & 217, &,- 028 & $\mid-131$ & 150 & 400, \\
\hline an ortaminı (toplumsal çevreyi) korur & 122 & , 010 & 767 & , 054 &,- 008 &,- 043 & 081 \\
\hline $\begin{array}{l}\text { Turizmin gelişmesinin çevr } \\
\text { güçlendireceğini düşünüyo }\end{array}$ & ,025 & ,118 & ,729 & 193 & ,071 &,- 076 & 093 \\
\hline iller için turizmin çevreyi geliştirdiğine & 079 & ,094 & ,644 & , 089 &,- 088 & 169 &,- 019 \\
\hline $\begin{array}{l}\text { Turiz } \\
\text { olum }\end{array}$ & 137, & ,134 & ,622 & 203 &,- 044 & 156 &,- 008 \\
\hline $\begin{array}{l}\text { Turiz } \\
\text { gelişn }\end{array}$ & 220 & ,138 & ,572 & 423 &,- 032 &,- 039 & 116 \\
\hline eli ve korunmalıdır & ,177 & ,161, & , 085 & ,803 &,- 063 & ,072 & 025 \\
\hline Çevre & ,157 & ,133 & ,161 & ,750 &,- 014 & 010 & , 070 \\
\hline $\begin{array}{l}\text { Turiz } \\
\text { stand }\end{array}$ & 188 & ,212, & 177, & 686 &,- 013 & , 019 & , 027 \\
\hline $\begin{array}{l}\text { Turizi } \\
\text { alanla }\end{array}$ & 1 & ,215 & ,222 & 615 &,- & 123 & 12 \\
\hline alitesini $b$ &,- 031 & ,010- & -213 &,- 042 & 734 & 103 & 054 \\
\hline $\begin{array}{l}\text { Toplumda turizm faaliyetleri } \\
\text { rahatsız oluyorum }\end{array}$ &,- 042 &,- 106 &, 0 & 158 &, 717 & 280 & 064 \\
\hline Turizm y &,- 149 &,- 066 &, 072 &,- 123 &, 647 & ,311 & 157 \\
\hline Yerel turizm işletmelerinden memnun değilim & 000 &,- 001 &,- 043 & 163 & ,638 &,- 032 &,- 014 \\
\hline $\begin{array}{l}\text { Turizmin gelişimi için alı } \\
\text { herkesi içermediğinde sıl }\end{array}$ & ,080 & ,184 & ,331 &,- 232 &, 474 &,- 055 & $-0,016$ \\
\hline Turiz & ,147 & , 136 & ,092 &,- 018 &, 000 & ,692 &,- 109 \\
\hline Turizmin gelişmesi ile toplum a &,- 022 & ,138 &, 019 & 103 & ,203 & ,637 & ,189 \\
\hline $\begin{array}{l}\text { Topluma ait olan rekreasyonel- boş zaman kullanımına } \\
\text { konu olan kaynaklar turistler tarafından aşırı kullanılır }\end{array}$ & ,057 & ,019, & ,047, & 118, & ,283 & ,626 & 111, \\
\hline $\begin{array}{l}\text { Turizm işletmeleri işgörenlerinin en az yarısını yerli halktan } \\
\text { oluşturmalıdır }\end{array}$ & 388, & ,139, & ,024, & 123, & ,124 &,-- 008 & 604, \\
\hline $\begin{array}{l}\text { Turizm yatırımları geliştirdikleri mal ve hizmetlerin en az } \\
\text { yarısı yerel topluluktan oluşturulmalıdır }\end{array}$ & 357, & ,203, & , 021, & 154, & 143 &,- 016 & 593, \\
\hline Turistler yaşam kalitemizi bozar & 163 &,- 19 & 57 &,- 005 & ,134 & 263 & 439 \\
\hline $\begin{array}{l}\text { Toplumdaki herkesin turizm kararlarına katılımı başarılı bir } \\
\text { turizm gelişimi için gereklidir }\end{array}$ & 334 & ,379 & 170, & 022, &,- 183 & 152 & 408, \\
\hline \multicolumn{8}{|l|}{ Ortaya Çıkarma Yöntemi: Ana Unsurlar Analizi. } \\
\hline
\end{tabular}


Faktör analizi sonuçlarına bakıldığında veri seti 7 faktör grubu altında toplanmıştır ve 7 faktör grubu toplam varyansın \% 54,892'sini açılamaktadır. Özdeğer istatistiği (Eigenvalue) 1'den büyük olan 9 boyut ilk faktör grubunu oluşturmaktadır ve toplam varyansın \% 26,108'ini açılamaktadır. Birinci faktör grubunda yer alan boyutların ortak özellikleri göz önüne alındığında planlama, başarı ve tatmin unsurlarının ön plana çıktığı görülmektedir. Bu nedenle birinci faktör grubu "Tatmine dayalı başarı planlaması" olarak adlandırılmıştır. İkinci faktör grubunda toplam 8 boyut toplam varyansın \% 8,041'ini açıklamaktadır. İkinci faktör grubunda yer alan boyutlar ortak özelliklerine göre "Ekonomik $f a y d a^{\prime \prime}$ şeklinde isimlendirilmiştir. Üçüncü faktör grubu toplam beş alt boyut ile varyansın \% 6,11'ini açıklamakta ve ortak özellikleri doğrultusunda "Toplumsal çevre" boyutu olarak adlandırılmaktadır. Dördüncü faktör grubu "Doğal çevre ve tabiat" boyutudur. Doğal çevre ve tabiat faktör boyutu toplam dört alt boyuttan oluşmakta ve toplam varyansın \% 4,72'sini açılamaktadır. Beşinci faktör boyutu 5 alt boyuttan oluşarak toplam varyansın \% 3,907'sini açılamaktadır ve "Sosyal maliyet" faktör boyutu olarak adlandırılmaktadır. Altıncı faktör boyutu üç alt boyuttan oluşmakta ve toplam varyansın \% 3,161'ini açıklamaktadır. Altıncı faktör boyutu araştırmada "Büyüme maliyeti" olarak adlandırılmıştır. Yedinci ve son faktör boyutu dört alt boyuttan oluşan "Turizmin yerlilere etkisi" boyutudur. Turizmin yerlilere etkisi boyutu toplam varyansın \% 2,844'ünü açıklamaktadır.

Araştırmanın temel amaçları doğrultusunda yapılan istatistiki hipotez testleri yapılmıştır. Araştırmada katılımclardan elde edilen veriler doğrultusunda" cinsiyet, eğitim görülen bölüm, katılımcıların eğitim gördükleri bölümün turizm bölümü olup olmaması, tatil deneyimlerinin olup olmaması, tatil deneyiminde konaklama işletmesinde geçirilen süre, tatil deneyiminde kalınan konaklama işletmesi türü, katılımcıların aylık ortalama harcama miktarı ve Burdur'da yaşam süresi" boyutları bağımsız değişkenler olarak belirlenmiştir. Faktör analizi sonucunda ortaya çıan turizm sürdürülebilirliği üzerine turumlar tatmine dayalı başarı planlaması, ekonomik fayda, toplumsal çevre, doğal çevre ve tabiat, sosyal maliyet, büyüme maliyeti ve turizmin yerlilere etkisi boyutları ise bağımlı değişken olarak ele alınmıştır. Bu bilgiler ışığında araştırma hipotezleri:

$1 \mathrm{H}_{0}$ : “Cinsiyet farklılı̆̆ ile üniversite öğrencilerinin turizm sürdürülebilirliği üzerine tutumların alt boyutları arasında fark yoktur".

2Ho: "Eğitim görülen bölüm farklılığı ile üniversite öğrencilerinin turizm sürdürülebilirliği üzerine tutumların alt boyutları arasinda fark yoktur".

3Нo: Eğitim görülen bölümün turizm bölümü olup olmaması farklılığı ile üniversite öğrencilerinin turizm sürdürülebilirliği üzerine tutumların alt boyutları arasında fark yoktur.

4Ho: “Tatil deneyimi ile üniversite öğrencilerinin turizm sürdürülebilirliği üzerine tutumların boyutları arasinda fark yoktur".

5Ho: "Tatil deneyiminde konaklama işletmesinde geçirilen süre ile üniversite öğrencilerinin turizm sürdürülebilirliği üzerine tutumların alt boyutları arasında fark yoktur"

6Ho: "Tatil deneyiminde kalınan konaklama işletmesi türü ile üniversite öğrencilerinin turizm sürdürülebilirliği fark yoktur".

7Ho: “Aylık ortalama harcama miktarı ile üniversite öğrencilerinin turizm sürdürülebilirliği üzerine tutumları arasında fark yoktur".

$8 \mathrm{H}_{0}$ : "Burdur'da yaşam süresi ile üniversite öğrencilerinin turizm sürdürülebilirliği üzerine tutumları arasında fark yoktur" olarak kurulmuştur. 
Tablo 5: Hipotez Testleri

\begin{tabular}{|c|c|c|c|c|c|c|c|c|c|c|c|c|c|c|c|c|}
\hline & \multicolumn{2}{|c|}{ Cinsiyet } & \multicolumn{2}{|l|}{ Bölüm } & \multicolumn{2}{|c|}{$\begin{array}{l}\text { Turizm- } \\
\text { Diğer } \\
\text { Bölümler }\end{array}$} & \multicolumn{2}{|c|}{$\begin{array}{l}\text { Tatil } \\
\text { Deneyimi }\end{array}$} & \multicolumn{2}{|c|}{ Tatil Süresi } & \multicolumn{2}{|c|}{$\begin{array}{l}\text { Konaklama } \\
\text { İşletmesi Türü }\end{array}$} & \multicolumn{2}{|c|}{$\begin{array}{l}\text { Harcama } \\
\text { Miktarı }\end{array}$} & \multicolumn{2}{|c|}{$\begin{array}{l}\text { Burdur'da } \\
\text { Yaşam Süresi }\end{array}$} \\
\hline & 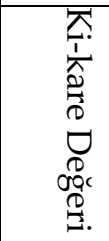 & 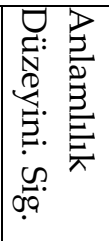 & 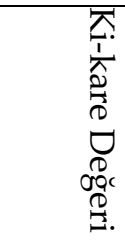 & 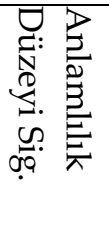 & 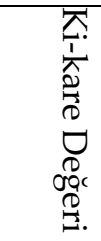 & 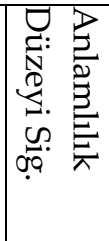 & 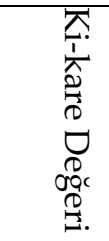 & 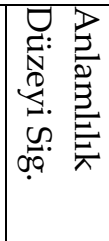 & 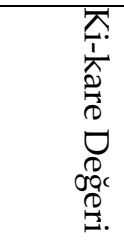 & 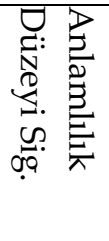 & 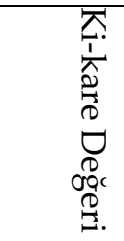 & 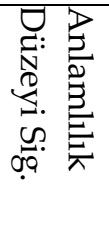 & 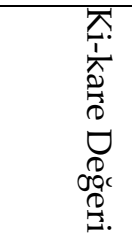 & 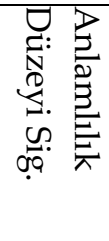 & 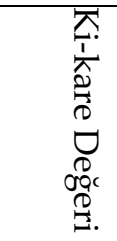 & 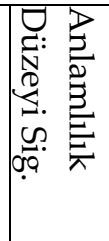 \\
\hline $\begin{array}{l}\text { Tatmine } \\
\text { Dayalı Başarı } \\
\text { Planlaması }\end{array}$ & 8,854 & 0,003 & 1,012 & 0,798 & 0,025 & 0,875 & 0,655 & 0,418 & 14,200 & 0,716 & 6,711 & 0,460 & 61,862 & 0,307 & 59,562 & 0,143 \\
\hline $\begin{array}{l}\text { Ekonomik } \\
\text { Fayda }\end{array}$ & 4,295 & 0,038 & 2,663 & 0,447 & 0,126 & 0,723 & 1,915 & 0,166 & 21,693 & 0,246 & 11,284 & 0,127 & 65,239 & 0,212 & 39,803 & 0,823 \\
\hline $\begin{array}{l}\text { Toplumsal } \\
\text { Çevre }\end{array}$ & 0,640 & 0,424 & 4,963 & 0,175 & 0,279 & 0,597 & 0,132 & \begin{tabular}{|l|}
0,717 \\
\end{tabular} & 16,697 & 0,544 & 1,525 & 0,981 & 65,022 & 0,218 & 42,085 & 0,747 \\
\hline $\begin{array}{l}\text { Doğal Çevre } \\
\text { ve Tabiat }\end{array}$ & 6,661 & 0,010 & 2,615 & 0,455 & 0,644 & 0,422 & 0,080 & \begin{tabular}{|l}
0,777 \\
\end{tabular} & 35,910 & 0,007 & 3,763 & 0,807 & 65,927 & 0,196 & 62,339 & 0,096 \\
\hline Sosyal Maliyet & 7,829 & 0,005 & 6,517 & 0,089 & 0,000 & 0,984 & 0,879 & 0,348 & 19,863 & 0,341 & 5,469 & 0,603 & 68,121 & 0,149 & 56,068 & 0,227 \\
\hline $\begin{array}{l}\text { Büyüme } \\
\text { Maliyeti }\end{array}$ & 2,828 & 0,093 & 5,031 & 0,170 & 3,815 & $\mid 0,051$ & 0,454 & $\mid 0,500$ & 20,423 & 0,309 & 11,313 & 0,126 & 62,322 & 0,293 & 48,914 & 0,477 \\
\hline $\begin{array}{l}\text { Turizmin } \\
\text { Yerlilere Etkisi }\end{array}$ & 0,358 & 0,550 & 14,664 & 0,002 & 1,048 & 0,306 & 0,027 & 0,869 & 14,986 & 0,663 & 14,648 & 0,041 & 54,095 & 0,585 & 80,663 & 0,003 \\
\hline
\end{tabular}


Bağımsız ve bağımlı değişkenleri yansıtan veriler normal dağılıma uymamaktadır. Verilerin normal dağılıma uymaması nedeni ile hipotez testleri parametrik olmayan testlerden çoklu bağımsız örneklem (K Independent Sample) Kruskal Wallis testi aracılığı ile ölçülmüştür. Hipotez testleri sonucunda ilk olarak "Cinsiyet farklılığı ile üniversite öğrencilerinin turizm sürdürülebilirliği üzerine tutumları arasında anlamlı fark olduğu" bu farkın "tatmine dayalı başarı planlaması boyutu tutumları, ekonomik fayda boyutu tutumları, doğal çevre ve tabiat boyutu tutumları ve sosyal maliyet boyutu tutumları" alt boyutlarından kaynaklandığı görülmektedir (Sig. $<0,05$ anlamlılık seviyesine göre). Eğitim görülen bölüm farklılığı ile üniversite öğrencilerinin turizm sürdürülebilirliği üzerine tutumları arasındaki ilişkiye bakıldığında, eğitim görülen bölüm farklılığı ile turizm sürdürülebilirliği üzerine tutumların alt boyutlarından turizmin yerlilere etkisi boyutu tutumları arasında anlamlı fark bulunmuştur. Hipotez testi sonucunda tatil deneyiminde konaklama işletmesinde geçirilen sürenin turizm sürdürülebilirliği tutumlarından doğal çevre ve tabiat tutumunu etkilediği görülmektedir. Tatil deneyiminde kalınan konaklama işletmesi türü ve Burdur'da yaşam süresi bağımsız değişkenlerinin, alt boyutlardan sadece turizmin yerlilere etkisine yönelik tutumlarını etkilediği görülmektedir.

Bir sonraki aşamada hipotez testi bulgularına göre aralarında anlamlı fark görülen değişkenlerin, anlamlılık düzeylerini belirlemek ve anlamlı farkların yorumlanabilmesi için korelasyon ve kümeleme testleri yapılmıştır.

Tablo 6: Korelasyon Testleri

\begin{tabular}{|c|c|c|c|c|c|c|c|c|c|c|}
\hline & \multicolumn{2}{|c|}{ Cinsiyet } & \multicolumn{2}{|c|}{ Bölüm } & \multicolumn{2}{|c|}{ Tatil Süresi } & \multicolumn{2}{|c|}{$\begin{array}{c}\text { Konaklama } \\
\text { İşletmesi } \\
\text { Türü }\end{array}$} & \multicolumn{2}{|c|}{$\begin{array}{c}\text { Burdur'da } \\
\text { yaşam süresi }\end{array}$} \\
\hline & 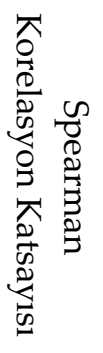 & 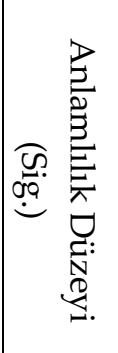 & 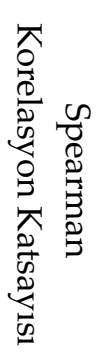 & : & 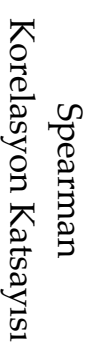 & 总 & 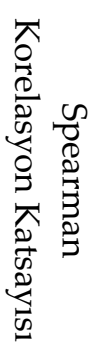 & 焉 & 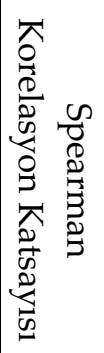 & 总 \\
\hline $\begin{array}{l}\text { Tatmine Dayalı } \\
\text { Başarı Planlaması }\end{array}$ & $-0,119$ & 0,003 & - & - & - & - & - & - & - & - \\
\hline Ekonomik Fayda & $-0,083$ & 0,038 & - & - & - & - & - & - & - & -- \\
\hline Toplumsal Çevre & - & - & - & - & - & - & - & - & - & \\
\hline $\begin{array}{l}\text { Doğal Çevre ve } \\
\text { Tabiat }\end{array}$ & 0,103 & 0,010 & - & - & $-0,139$ & 0,010 & - & - & - & - \\
\hline Sosyal Maliyet & $-0,112$ & 0,005 & - & - & - & - & - & - & - & - \\
\hline Büyüme Maliyeti & - & - & - & - & - & - & - & - & - & - \\
\hline $\begin{array}{l}\text { Turizmin Yerlilere } \\
\text { Etkisi }\end{array}$ & - & - & 0,077 & 0,054 & - & - & $-0,031$ & 0,527 & $-0,082$ & 0,087 \\
\hline
\end{tabular}

Korelasyon testi sonuçlarına göre cinsiyet ile tatmine dayalı başarı planlaması, ekonomik fayda, doğal çevre ve tabiat ile sosyal maliyet boyutları arasındaki korelasyon ilişkisi anlamlı çıkmıştır (Sig.<0,05). Ancak korelasyon ilişkisinin çok zayıf düzeylerde olduğu görülmektedir. Öğrencilerin eğitim gördüğü bölüm ile turizmin yerlilere etkisi boyutu arasında anlamlı bir korelasyon ilişkisi görülmemektedir (Sig. $>0,05)$. Tatil süresi ile doğal çevre ve tabiat değişkenleri arasında anlamlı ancak çok zayıf korelasyon olduğu görülmektedir (Sig.<0,05). Tatil deneyiminde tercih edilen konaklama işletmesi türü ve Burdur'da yaşam süresi ile turizmin yerlilere etki değişkenleri arasında da anlamlı bir korelasyon ilişkisi çıkmadığı görülmektedir. 
Tablo 7: Katılımcıların Cinsiyete Göre Turizm Sürdürülebilirliği Üzerine Tutumlar Kümeleme Testi Sonuçları

\begin{tabular}{|c|c|c|c|c|c|c|c|c|c|}
\hline & \multirow{2}{*}{\multicolumn{2}{|c|}{$\begin{array}{c}\text { Kümede } \\
\text { Yer Alan } \\
\text { Veri } \\
\text { Sayısı } \\
\end{array}$}} & \multirow{2}{*}{\multicolumn{2}{|c|}{$\begin{array}{c}\text { Son } \\
\text { Küme } \\
\text { Merkezler } \\
\text { i } \\
\end{array}$}} & \multicolumn{4}{|c|}{ Cinsiyetin Gruplara Göre Dağılımı } & \multirow{3}{*}{$\begin{array}{c}\text { Anlamlılık } \\
\text { Düzeyi } \\
\text { (Sig.) }\end{array}$} \\
\hline & & & & & \multicolumn{2}{|c|}{1} & \multicolumn{2}{|c|}{2} & \\
\hline & 1 & 2 & 1 & 2 & Kadın & Erkek & Kadın & Erkek & \\
\hline $\begin{array}{l}\text { Tatmine } \\
\text { Dayalı Başarı } \\
\text { Planlaması }\end{array}$ & \multirow[t]{4}{*}{578} & \multirow[t]{4}{*}{44} & 4,11 & 2,45 & \multirow[t]{4}{*}{$\begin{array}{c}367 \\
(\% 63,49)\end{array}$} & \multirow[t]{4}{*}{$\begin{array}{c}211 \\
(\% 36,51)\end{array}$} & \multirow[t]{4}{*}{$\begin{array}{c}19 \\
(\% 43,18)\end{array}$} & \multirow[t]{4}{*}{$\begin{array}{c}25 \\
(\% 56,82)\end{array}$} & 0,000 \\
\hline $\begin{array}{l}\text { Ekonomik } \\
\text { Fayda }\end{array}$ & & & 4,12 & 2,22 & & & & & 0,000 \\
\hline $\begin{array}{l}\text { Doğal Çevre } \\
\text { ve Tabiat }\end{array}$ & & & 4,65 & 2,79 & & & & & 0,000 \\
\hline $\begin{array}{l}\text { Sosyal } \\
\text { Maliyet }\end{array}$ & & & 2,39 & 2,66 & & & & & 0,036 \\
\hline
\end{tabular}

Cinsiyet değişkenine göre kümeleme analizi yapıldığında iki kümeye göre, kümeler arasında turizm sürdürülebilirliği üzerine tutumlar arasında anlamlı ilişki bulunmuştur. Son küme merkezi değerlerine göre birinci küme tatmine dayalı başarı planlaması, ekonomik fayda ve doğal çevre ve tabiat boyutlarında sürdürülebilirlik tutumları ikinci kümeye göre çok daha yüksektir. Birinci kümede kadın oranı daha yüksek iken, ikinci kümede oransal olarak erkekler daha fazla sayıdadır. Ancak birinci kümede veri yoğunluğu ikinci kümeye oranla çok daha yüksek olması nedeni ile söz konusu farklılık sadece cinsiyete bağlanamamaktadır. Bu nedenle verilere ait küme üyeliği (cluster membership) tablosu incelenmiştir. Birinci kümedeki verilerin ortak bir özelliği belirgin olarak ortaya çıkmazken, ikinci kümedeki cevaplayıcılardan kadınların \% 94, 74 (18 üçüncü sınıf, 1 birinci sınıf)'ünün ve erkeklerin \% 88 (22 üçüncü sınıf, 2 ikinci sınıf, 1 birinci sınıf)'inin üçüncü sınıf öğrencisi olduğu görülmüştür.

Tablo 8: Tatil Süresine Göre Turizm Sürdürülebilirliği Üzerine Tutumlar Kümeleme Testi Sonuçları

\begin{tabular}{|l|c|c|c|c|c|c|c|}
\hline & \multicolumn{3}{|c|}{$\begin{array}{c}\text { Kümede Yer Alan Veri } \\
\text { Sayıs }\end{array}$} & \multicolumn{3}{c|}{ Son Küme Merkezleri } & $\begin{array}{c}\text { Anlamlılık } \\
\text { Düzeyi } \\
\text { (Sig.) }\end{array}$ \\
\cline { 2 - 7 } & 1 & 2 & 3 & 1 & 2 & 3 & 0,000 \\
\hline Doğal Çevre ve Tabiat & 71 & 535 & 25 & 3,72 & 4,75 & 1,48 & 0 \\
\hline
\end{tabular}

Verilerin kümeleme analizine tabi tutulabilmesi için tatilde yılda ortalama kaç günün konaklama işletmesinde geçirildiğine dair açık uçlu olarak sorularak elde edilen veriler yedi günden az, yedi-on üç gün, on dört-yirmi gün ve yirmi bir gün ve üzeri olarak sınıflanmıştır. Kümeleme analizi hipotez ve korelasyon testlerinin sonuçları dikkate alınarak aralarında anlamlı bir ilişki çıkan Doğal Çevre ve Tabiat boyutuna uygulanmıştır. Kümeleme analizi testinde veriler üç kümeye bölünmüştür. Verilerin büyük çoğunluğu (535 veri, \% 84,79) ikinci kümede toplanmıştır. Son küme merkezleri bulguları ikinci kümenin doğal çevre ve tabiat boyutu açısından turizm sürdürülebilirliğine 4,75 ortalama değer ile çok yüksek önem verdiği; birinci kümenin 3,72 ortalama değer ile orta-yüksek değer verdiği; üçüncü kümenin ise 1,48 ortalama ile değer vermediği anlaşılmaktadır ( 1 en düşük, 5 en yüksek). Anlamlılık düzeyi açısından kümeleme testinin istatistiki olarak anlamlı olduğu görülmektedir (Sig. $<0,05)$. 
Tablo 9: Tatil Süresine Göre Turizm Sürdürülebilirliği Üzerine Tutumlar Kümeleme Testi Gruplara Göre Verilerin Dağılımı

\begin{tabular}{|c|c|c|c|c|c|c|c|c|c|c|c|c|}
\hline \multicolumn{13}{|c|}{ Tatil Sürelerinin Gruplara Göre Dağılımı } \\
\hline Gruplar & \multicolumn{4}{|c|}{1} & \multicolumn{4}{|c|}{2} & \multicolumn{4}{|c|}{3} \\
\hline 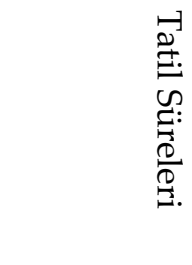 & 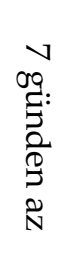 & $\begin{array}{c}\stackrel{N}{\omega} \\
\stackrel{\omega}{c} \\
\stackrel{\Xi}{\Xi}:\end{array}$ & 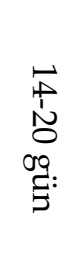 & 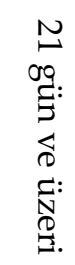 & 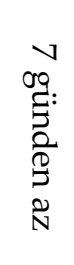 & 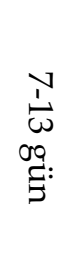 & 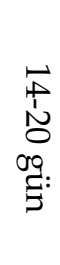 & 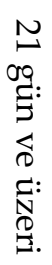 & 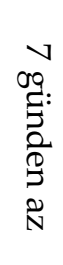 & $\begin{array}{c}\stackrel{N}{.} \\
\omega \\
\stackrel{\sigma}{\Xi}: \\
\Xi\end{array}$ & 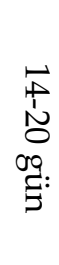 & 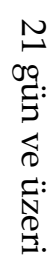 \\
\hline Kişi Sayısı & 9 & 19 & 32 & 11 & 214 & 285 & 32 & 4 & 19 & 5 & 1 & 0 \\
\hline
\end{tabular}

Verilere ait küme üyeliği (cluster membership) tablosu incelendiğinde birinci grup üyeleri yıl içerisinde ortalama gün sayısı olarak en fazla tatil yapan bireylerden oluşmaktadır. İkinci grup üyelerinin konaklama işletmelerinde tatil geçirme sürelerinin yedi günden az ve yedi-on üç gün merkezinde toplandığ 1 görülmektedir. Üçüncü grup üyeleri ise diğer gruplara oranla yılda ortalama tatillerini konaklama işletmelerinde az geçiren bireylerden oluşmaktadır. Her iki tablodaki veriler göz önüne alındığında konaklama işletmelerinde tatil süreleri 13 güne kadar olanların (ikinci grup) doğal çevre ve tabiat açısından turizm sürdürülebilirliğine yönelik tutumlarının daha yüksek olduğu, 13 günden fazla olan grubun (birinci grup) tutumlarının orta düzeyde olduğu, tatil süreleri yedi günden az olan grubun (üçüncü grup) ise tutumlarının düşük olduğu söylenebilir.

Araştırma bulgularına göre kadınların erkeklere oranla turizm işletmeleri ve turistik ürünlerin tüketici tatmini sağlamasına daha fazla önem vermesi gerektiğini düşünmektedirler. İkinci olarak yine kadınlar erkeklere oranla turizmin ekonomiye katkısının daha yüksek olduğunu ve turizmin sürdürülebilirliği açısından doğa ve tabiat varlıklarının korunmasına daha fazla önem verilmesi gerektiğini düşünmektedirler. Bu durum kadınların turizm deneyimlerinden tatmin olma konusunda erkeklere oranla daha fazla önem verdikleri, bir başka deyişle beklentilerinin karşılanmasının erkeklere oranla çok daha önemli olduğu şeklinde yorumlanabilir. Söz konusu durum turizm pazarlaması konusunda cinsiyet açısından beklenti ve tatmin çalışmaları bulguları ile örtüşmektedir (Martin vd., 2019; Akıncı ve Aksoy, 2019). Yıl içerisinde geçirilen tatil süreleri göz önüne alındığında tatil süresi arttıkça doğa ve tabiat varlıklarının korunmasına daha fazla önem verildiği görülmektedir. Bu sonuç turizme hareketine katılım yoğunlaştıkça doğal varlıkların öneminin ve sürdürülebilirliğinin öneminin tüketiciler tarafından daha fazla anlaşıldığı yönünde yorumlanabilir.

\section{SONUÇ VE ÖNERILER}

Turizm doğal ve kültürel çekiciliklerin alt ve üst yapı tamamlayıcıları ile birlikte ürün haline getirilmesi ve turistlerin bu ürünü tüketmek istemeleri sonucunda ortaya çıkan bir olgudur. Bu bağlamda çekim yerleri açısından turizm faaliyetlerinin devamlılığı açısından sürdürülebilirlik önemli bir kavramdır. Turizmin sürdürülebilir olması için yerel halkın, yerel yönetimlerin ve turistik ürünü kullanan turistlerin sürdürülebilirliği üzerine tutumları önem taşımaktadır.

Üniversite öğrencileri genç nüfus içerisinde yer almakla birlikte, gelir düzeyleri, boş zamanları, sosyal çevreleri ve genel yaşam şekilleri ile diğer gençlerden farklılaşmaktadır. Tam zamanlı çalışma imkanlarının sınırlı oluşu dışındaki diğer özellikleri üniversite öğrencilerini tatile çıkma davranışını olumlu etkilemektedir. Bu nedenle üniversite öğrencileri önemli bir turist potansiyeline sahiptir. Diğer yandan üniversite öğrencileri aldıkları eğitim gereği geleceği şekillendirme potansiyeline sahip bireylerdir. Bu nedenle üniversite öğrencilerinin turizm sürdürülebilirliğine yönelik tutumları turizm sürdürülebilirliği için önemlidir. 
Araştırmada Mehmet Akif Ersoy Üniversitesi öğrencilerinin turizm sürdürülebilirliği üzerine tutumları incelenerek, öğrencilerin eğitim aldıkları bölüm, tatil deneyimlerinin olup olmaması, tatilde konaklama işletmelerinde geçirilen süre, tatil deneyiminde genelde konaklanan işletme türü, aylık ortalama harcama miktarı, Burdur'da geçirilen yaşam süresi, turizm eğitimi almak ve cinsiyet değişkenleri ile turizm sürdürülebilirliğinin alt boyutları arasında bir ilişki bulunup bulunmadığı incelenmiştir.

Araştırma verilerinden elde edilen bulgular; konaklama işletmesinde geçirilen süre ile doğal çevre ve tabiat tutumları alt boyutu; tatil deneyiminde kalınan konaklama işletmesi türü ve Burdur'da yaşam süresi ile turizmin yerlilere etkisine yönelik tutumları alt boyutu ve cinsiyet ile tatmine dayalı başarı planlaması boyutu, ekonomik fayda boyutu, doğal çevre ve tabiat boyutu ve sosyal maliyet boyutu tutumları arasında anlamlı ilişki olduğunu göstermiştir.

Hipotez testine göre eğitim görülen bölüm ile turizm sürdürülebilirliği tutumlarından sadece turizmin yerlilere etkisi alt boyutu arasında ilişki çıkması ve bu ilişkinin de korelasyon testi verilerine göre yeterli olmaması ilginç bir bulgudur. Örneklem grubunda yer alan öğrencilerden turizm öğrencileri turizm sürdürülebilirliği ile ilgili dersler almakta, diğer bölüm öğrencileri ise konu ile ilgili eğitim almamaktadır. Bu duruma rağmen arada anlamlı bir fark çıkmamasının nedeni turizm öğrencilerinin turizmde sadece turist olarak yer almayıp, ayrıca staj ve yaz tatili çalışmaları ile çalışan olarak turizm sektöründe yer alması ve sektörde yaşadığı deneyimlerden kaynaklı olabilir. Söz konusu sonucun bahsedilen nedenden, verilen sürdürülebilir turizm eğitimlerinin amacına ulaşmamasından veya farklı bir nedenden kaynaklı olup olmadığı gelecekteki çalışmalar için incelenmeye değer bir konudur.

Tatilde konaklama işletmelerinde geçirilen süresinin artması aynı zamanda tatil yapma yoğunluğunun da bir göstergesidir. Yıl içerisinde daha fazla tatil yapan bireylerin turizm sürdürülebilirliği konusunda doğal çevre ve tabiat tutumları arasındaki ilişkinin yüksek çıkması akademik yazında da sıklıkla vurgulanan turizme katılanların çevre sürdürülebilirliği üzerine olumlu tutumları olması görüşü ile örtüşmektedir ve turizmin çevre sürdürülebilirliği açısından olumlu bir bulgudur.

Tatil deneyiminde genelde konaklanan işletme türü ile turizmin yerlilere etkisi sürdürülebilirlik alt tutumu ile ilgili olan ilişki genel olarak bir mantık çerçevesine oturmasa da, Burdur'da yaşam süresi arttıkça yerlilerle ilişkilerin artacağı düşünüldüğünde, Burdur'da yaşam süresi arttıkça turizmin yerlilere yönelik etkisinin önemi daha fazla anlaşıldığı sonucuna ulaşılmaktadır.

Araştırmada cinsiyet ile turizme yönelik sürdürülebilirlik tutumları ile ilgili en yoğun ilişki cinsiyet değişkeninde görülmüştür. Kadın katılımcıların turizm sürdürülebilirliği tutumları erkek katılımcılara oranla çok daha yoğun görülmektedir. Bu bağlamda kadın üniversite öğrencilerinin turizmin sürdürülebilirliği konusunu daha benimseyici olduğu söylenebilir. Kümeleme analizi sonucunda söz konusu tutum farklılığının üçüncü sınıf erkek ve üçüncü sınıf kadın öğrenciler arasında iyice yoğunlaşması, üniversite eğitiminin kadın ve erkek öğrencileri turizm sürdürülebilirliği konusunda farklı etkilediği şeklinde yorumlanabilir. Bu konuda daha kesin yargılara varılabilmesi için gelecekte yeni çalışmalara ihtiyaç vardır.

Tatil süresine göre turizm sürdürülebilirliği üzerine tutumlar kümeleme testi ile incelendiğinde yıl içerisinde tatilde konaklama işletmelerinde daha fazla geceleme yapanların turizmin sürdürülebilirliği üzerine tutumlarının diğerlerine göre bir hayli yüksek derecede anlamlı olduğu görülmektedir. Bu durum tatile çıkma davranışı sıklaştıkça sürdürülebilirliği destekleyici tutumların da arttığını göstermektedir. Başka bir deyişle turizmin sürdürülebilirliğinin sağlanmasında turizme yoğun katılımın önemi büyüktür.

Araştırmada üniversite öğrencilerinin eğitim aldıkları alana göre turizm sürdürülebilirliği açısından tutumları arasında bir fark olup olmadığı incelendiğinde anlamlı bir fark görülememiştir. Turizm alanında eğitim alan öğrenciler gerek turizmin genel oluşum yapısı, önemi gibi konularda gerekse turizmin sürdürülebilirliği konusunda eğitim almaktadırlar. Turizm ve turizm sürdürülebilirliği konusunda eğitim alan hatta staj ve uygulama dersleri aracılığı ile turizm içerisinde çalışan olarak da yer alan bir kitlenin turizm ve sürdürülebilirliği açısından diğer alanlarda eğitim alanlardan farklı bir 
bakış açısına sahip olmaması ilgi çekici bir bulgudur. Bu durumun nedenleri arasında öğrencilerin turizm işletmelerinde çalışmaları sonucunda başta kar olmak üzere kısa vadeli işletme çıkarları konusunu tutumlarına yansıtması olabilir. Diğer yandan bu durumun bir başka nedeni aldıkları genel eğitim içerisinde sürdürülebilirlik konusunun yeterince önem verilerek işlenmemesi veya öğrenciler tarafından doğru şekilde algılanmaması olabilir. Oysaki turizm eğitimi alan öğrencilerin geleceğin turizm yöneticisi olma ve turizmi şekillendirme potansiyelleri bir hayli yüksektir. Bu bağlamda turizm öğrencilerinin sürdürülebilirlik kavramının önemini kavrayabilmelerinin önemi büyüktür. Gelecekteki çalışmalarda turizm öğrencilerinin turizm sürdürülebilirliğine bakış açılarının, aldıkları eğitim açısından incelenerek sebeplerin bulunması ve sürdürülebilir turizme yönelik olumlu tutumlarının arttırılması yollarının ortaya konması önem taşımaktadır.

Araştırma sadece Mehmet Akif Arsoy Üniversitesi'nde belirli bölümlerde eğitim gören öğrencilere yönelik olarak yapılmıştır. Üniversitenin büyük bir şehirde yer almaması, öğrencilerin belli bölümlerden seçilmiş olması araştırmanın sınırlılıklarındandır. Bu nedenle büyük şehir üniversiteleri, vakıf ve özel üniversiteler ve üniversitelerin diğer bölümlerinde eğitim gören öğrencileri de kapsayan bir çalışmanın gelecekte yapılması akademik yazına yeni katkılar yapabilecektir.

Araştırmada öğrencilerin turizm sürdürülebilirliği ile ilgili eğitim alıp almadıkları, turizm sektöründe çalışıp çalışmadıkları gibi bilgilere yer verilmemiştir. Ancak araştırma sonuçları bu konularında incelenmesi ile yeni bulgulara ulaşılabileceğinin ipuçlarını vermektedir.

Araştırmada örneklemden veriler beşli Likert yöntemi ile toplanıp veriler nicel yöntemlerle incelenmiştir. Gelecek araştırmalarda katılımcıların sürdürülebilirlik konusundaki görüşlerinin nitel olarak incelenmesi ile yeni ve daha derinlemesine bulgulara ulaşılabilir.

\section{KAYNAKÇA}

Akıncl, S. and Aksoy, Ş. (2019). The Impact of Service Recovery Evaluation on Word-Of-Mouth Intention: Amoderated Mediation Model of Overall Satisfaction, Household Income and Gender, Tourism Management Perspectives, 31, 184-194.

Ayaz, N. Yeşiltaş, M. ve Türkmen, F. (2012). Turizm Eğitimi Alan Öğrencilerin Kırsal Turizme Bakış Açıları ve Algıları Üzerine Bir Araştırma, KMÜ Sosyal ve Ekonomik Araştırmalar Dergisi, 14, (22), 103-112.

Budeanu, A. Miller, G. Moscardo, G. and Ooi, C. S. (2015). Sustanable Tourism, Progress, Challenges and Opportunities, An Introduction to This Special Volume, Journal of Cleaner Production, 111, 285-294.

Bywater, M. (1993). Market Segments: The Youth and Student Travel Market, Travel and Tourism Analyst, 3, 35-50.

Can, E. (2013), Turizm Destinasyonlarında Sürdürülebilir Turizmin Sürdürülebilir Rekabet Açısından Değerlendirilmesi, İstanbul Journal of Social Studie, 4, 23-40.

Carr, N. (2005). Poverty, Debt and Conspicuous Consumption: University Students Tourism Experiences, Tourism Management, 26, 797-806.

Çelik, N., ve Bahar, O., (2014), Sürdürülebilir Turizmin Turizm Talebi Üzerine Etkisi, 15. Ulusal Turizm Kongresi Bildiriler Kitabı, Engelsiz Turizm, 13-16 Kasım, Ankara, 368-383.

Davies, E. and Lea, S. (1995). Student Attitudes to Student Debt, Journal of Economic Psychology, 16 (4), 663-679.

Durlu Özkaya, F. Sünnetçioğlu, S. ve Can, A, (2013), Sürdürülebilir Gastronomi Turizm Hareketliliğinde Coğrafi İşaretlemenin Rolü, Journal of Tourism and Gastronomy Studies, 1 (1), 13-20.

Glasson, J. Godfrey, K. and Goodey, B. (1995), Toward Visitor Impact Managent, London Avebury. 
Gosling, J. (2004). Introductory Statistics a Comprehensive, Self-Paced, Step-By-Step Statistics Course for Tertiary Students. Pascal Press, Glebe-Australia.

Güdü Demirbulat, Ö. ve Tetik Dinç, N. (2017). Sürdürülebilir Turizm Konulu Lisansüstü Tezlerin Bibliyometrik Profili, Seyahat ve Otel İşletmeciliği Dergisi, 14 (2), 20-30.

Hardy, A. L. and Beeton, R. J. S. (2009), Sustainable Tourism or Maintainable Tourism: Managing Resources for More Than Average Outcomes, Journal of Sustainable Tourism, 9 (3), 168-192.

Jurowski, C. and Gürsoy, D. (2004). Distance Effects on Residents' Attitudes Towards Tourism, Annals of Tourism Research 31 (2), 296-312.

Kalaycı, Ş. (2005). SSPS Uygulamalı Çok Değişkenli İstatistik Teknikleri, Asil Yayın Dağıtım, Ankara.

Karakoç, F. Y. ve Dönmez, L. (2014). Ölçek Geliştirme Çalışmalarında Temel İlkeler, Tıp Eğitimi Dünyası Dergisi, 40, 39-49.

Kaypak, Ş. (2010). Ekolojik Turizmin Sürdürülebilirliği, Alanya İşletme Dergisi 2 (2), 93-114.

Khan, S. (2019). Travel Lifestyle of Young Indian Students: "Gender Distinct" or "Gender Blurred", International Journal of Hospitality and Tourism Systems, 12 (2), 17-26.

Kulaç, A. ve Mutlu Çamoğlu, S. (2015). Türkiye'de Beş Yıllık Kalkınma Planları Çerçevesinde Turizm Politikaları ve Gelişimi, Doğu Karadeniz Bölgesi Sürdürülebilir Turizm Kongresi, 14-16 Mayıs, Bildiri Kitabı, Gümüşhane, 35-45.

Kuter, N. ve Ünal, H. E. (2009), Sürdürülebilirlik Kapsaminda Eko-turizmin Çevresel, Ekonomik ve Sosyokültürel Etkileri, Kastamonu Üniversitesi Orman Fakültesi Dergisi 9 (2), 146-156.

Martin, J. C., Saayman, M. and du Plessis, E. (2019). Determining Satisfaction of International Tourist: A Different Approach, Journal of Hospitality and Tourism Management, 40, 1-10.

Ongun, U. Gövdere, B. ve Çelik, T. (2016). Turizm Eğitimi Alan Öğrencilerin Kırsal Turizme Bakış Açlarının Değerlendirilmesine Yönelik Nitel Bir Araştırma, Mehmet Akif Ersoy Üniversitesi Sosyal Bilimler Dergisi, 8 (17), 406-423.

Pritchard, A. and Morgan, N. J. (1996). Sex Still Sells to Generationx: Promotional Practice and The Youth Package Holiday Market, Journal of Vacation Marketing, 3 (1), $69-80$.

Sharma, S. (1996). Applied Multivariate Techniques, John Wiley \& Sons Inc., New York.

Sheldon, P. J. and Abenoja, T. (2001). Resident Attitudes in A Mature Destination: The Case of Waikiki, Tourism Management, 22, 435-443.

Smeaton, G. Josiam, B. and Dietrich, U. (1998). College Students' Bingedrinking at A Beachfront Destination During Spring Break, Journal of American College Health, 46 (6), 247-254.

Sonuç, N. (2014), Sürdürülebilir Turizm: Tanımı ve İçeriği, Sürdürülebilir Turizm KavramlarUygulamalar, (Ed., Kozak, M.), Detay Yayıncılık, 1. Baskı, Ankara. 13-28.

Suk, H. Choi S. C. and Sirakaya, E. (2005). Measuring Resident's Attitude toward Sustainable Tourism: Development of Sustainable Tourism Attitude Scale, Journal of Travel Research, 43, 380-394.

Weaver, D. (2008). Sustainable Tourism Elsevier Ltd. ISBN 978-0-7506-6438-7, NY, USA.

Yeni, O. (2014), Sürdürülebilirlik ve Sürdürülebilir Kalkınma Bir Yazın Taraması, Gazi Üniversitesi İktisadi ve İdari Bilimler Fakültesi Dergisi 16 (3), 181-208.

Yllmaz, İ. A. Ünal, A. ve Çakır, G. (2015). Sürdürülebilir Turizm Literatürü Üzerine Bir Değerlendirme: Türkiye Bağlamı, Mesleki Bilimler Dergisi 4 (2), 55-83. 